地 震 第 2 輯

第 46 巻（1993） 35-44 頁

\title{
強震動卓越方向の震源依存性と観測点依存性
}

\author{
一千葉アレーにおける 8〜 $10 \mathrm{~Hz}$ 地震動の主軸解析一
}

\author{
信州大学工学部* 泉 谷 恭男・寺 田 彰
}

\section{Source Effect and Site Effect on Predominant Direction of Strong Ground Motion}

\author{
-Principal Axis Analysis of $8 \sim 10 \mathrm{~Hz}$ Ground Motion \\ at Chiba Array-
}

Yasuo Izutani and Akira Terada

Faculty of Engineering, Shinshu University, 500 Wakasato, Nagano, 380, Japan

(Received February 25, 1993; Accepted April 19, 1993)

\begin{abstract}
The predominant directions of $8 \sim 10 \mathrm{~Hz}$ strong ground motions due to 17 earthquakes are examined through the principal axis analysis of S-wave records by a dense accelerometer array. It is found that each of the observation points belonging to the array has its own preferred direction of strong amplification, that is to say, the directional site resonance. The predominant directions of 8 $10 \mathrm{~Hz}$ strong ground motions due to S-waves appear to reflect both the directional site resonances and the polarization characteristics of incident waves. For the events with $M_{\mathrm{JMA}} \geq 5.0$, since the degree of polarization of incident waves is low probably because of their large fault dimensions, the predominant directions of strong ground motions tend to reflect the directional site resonances. On the other hand, the predominant directions of strong ground motions due to the events with $M_{\text {JMA }}<5.0$ are dominated by the characteristics of highly polarized incident waves.
\end{abstract}

Key words: Strong ground motion, Principal axis, Directional site resonance, Chiba Array database.

\section{§1.はじめに}

近距離で得られた強震動記録中の比較的振幅の大きい 部分は一般に S 波と考えられている.この S 波による地 震動の卓越方向が地震の発震機構に基づく地震波の放射 特性をごの程度反映しているかという問題は, 地震学的 にも地震工学的にも非常に興味深い.たとえば, 佐藤・ 他 (1979) は 1976 年 7 月 5 日の鬼首地震 $\left(M_{\mathrm{JMA}}=4.9\right)$ の際の墓石の転倒方向から地震動の卓越方向を推定し た. 更に, 推定した震動卓越方向と地震の発震機構から 期待される S 波の震動方向との比較から, 地震の際の断 層破壊過程について詳しく検討している.

一方, 大地震の際の強震動はあまり極端な卓越方向を 示さず，かなり等方化されてしまっているという見方も ある. 経験的グリーン関数法による強震動予測手法に関

* 于380 長野市若里 500
して入倉 (1990) は, 経験的グリーン関数としてその記 録を用いる小地震と, 強震動を予測しようとする大地震 の発震機構の違いについてどの様に考慮すべきかについ て検討している. その結果, 観測される強震動はかなり 等方化してしまっていて震源の放射特性をあまり強く反 映していないことを指摘し, 高周波数領域の放射特性は 決定論的には取り扱えず, 統計的に取り扱う必要がある 之述べている. 強震動の等方化の原因は層境界における 反射波や変換波の混入 [例えば， HERRMANN (1976), NUTTLI (1961)] の他に，伝播経路の媒質の不均質による 地震波の散乱の影響も大きいであろう[例えば, MATSUMURA (1981), 佐藤 (1991), ToKsöz et al. (1991)]。特 に短周期地震波に対しては, 観測点近傍の地表地形やご く表層の速度構造のゆらぎなども, 大きな影響を及ぼし ているであろう [例えば, AKI and LARNER (1970), KAWASE and AKI (1990), 堀家・他 (1991)]. 
Bonamassa and Vidale (1991) は 1989 年 10 月 18 日の Loma Prieta 地震の余震の震動卓越方向について 検討した。 その結果, 強震動のごく最初の部分は直達 S 波と考えられ, 震源での放射特性を反映しているが, 後 続の散乱波混入部分は発震機構に無関係に観測点毎に独 自の震動卓越方向を示すことを見出した。 また，VIDALE et al. (1991) は 1987 年 10 月 1 日の Whittier Narrows 地震の本震と, 10 月 4 日の余震の記録を解析し, 強震動 の卓越方向について調べた。本震の発震機構は低角の逆 断層であり, 余震は横ずれ断層である. 発震機構の違い から，2つの地震については $\mathrm{S}$ 波の震動方向が異なるこ とが期待される. それにあ拘らず，強震記録が得られた 13 観測点中 8 観測点において, 2 つの地震時の強震動 の卓越方向は非常に似ていた。これに基づいて VIDALE et al. (1991) は，入射してきた地震波をある特別な方向 にのみ強く増幅するような性質を各観測点の地盤が有し ていると結論づけこれを Directional Site Resonance と名付けた.

「ごく普通の」堆積地盤上で実際に観測される強震動 の卓越方向は, 震源での放射特性をどの程度反映してい るものであろう. 散乱等の影響で等方化されてしまって 卓越方向を示さないのであろうか。 それとも VIDALE et al. (1991) の指摘しているように, 地震動の卓越方向 は地震の違いには関係なく, 観測点毎に決ってしまって いるのであろうか.この問題に対する波動理論的な研究 が重要であることは言うまであないが，それに並行し て, 出来るだけ多くのデー夕を解析して実際に生じてい る事柄を検証することも必要である. 実際に観測される 強震動卓越方向特性に, 何の影響がどの程度含まれてい るかを調べることによって, 経験的な强震動予測のため の資料を得ることも出来るであろう，本論文は，非常に 密に設置された強震計アレー記録の解析によって,この 問題について検討した結果を報告するものである.

\section{§2. 千葉アレーデータベース}

東京大学生産技術研究所千葉実験所構内においては, 非常に密に加速度計を配置したアレー方式によって强震 観測が行われている [KATAYAMA et al. (1990a, b)]. 半 径約 $200 \mathrm{~m}$ の円内に含まれる 15 地点の地下 $1 \mathrm{~m}$ の深 さに加速度計が設置されている.このうちの 9 地点は半 径 $15 \mathrm{~m}$ の円内に集中している. また, これらの地点の うちには地下 $5 \mathrm{~m}, 10 \mathrm{~m}, 20 \mathrm{~m}, 40 \mathrm{~m}$ にも加速度計が設 置されている箇所むあり, 3 次元アレーを構成してい る. 1982 年から 1989 年までに記録された計 27 個の地 震の加速度記録がデータベース化され，公開されてい る. 計器設置の方位誤差はアレー記録の解析結果に重大
な誤りを生むであろうことが考えられ，補正の方法も検 討されている [佐藤・片山 (1983), 植竹・他 (1991)]. 千葉アレーにおいても計器の方位誤差については慎重に 検討され，データベース構築時に補正が施されている [Y АMAZAKI et al. (1992)]. このデータベースを用いた研 究は既に種々行われており, 本研究で解析しょうとして いる短周期成分の地震動に関しては, 同一地震の記録で ありながら観測点間のコヒーレンスが非常に小さいこと や，地震動主軸が観測点によってまちまちの方向を 示すことが指摘されている[例えば, KATAYAMA et al. (1990a, b)].

本研究においては，前節で述べたような観点から,こ のアレー内の複数の観測点で観測された複数の地震の際 の震動卓越方向について総合的に解釈することを試み る. 解析するデータは千葉アレー内 9 地点の地下 $1 \mathrm{~m}$ で観測された 17 地震の加速度記録である. Table 1 に 示したように地震のマグニチュードは 4.0 から 6.7 であ り, 震央距離が $70 \mathrm{~km}$ 以内の地震の記録のみを用いる. 千葉アレーの位置と地震の震央を Fig. 1 に示す. 地震番 号は KATAYAMA et al. (1990a, b)に従い，本論文では地 震番号の前に $\mathrm{EQ}$ という文字を付けて地震名称とする. $\mathrm{EQ} 16$ は 1987 年 12 月 17 日の千葉県東方沖地震であ り， $\mathrm{EQ} 17 \sim \mathrm{EQ} 21$ はその余震である. 9 観測点は半径 $15 \mathrm{~m}$ の円内に集中しており，C0〜C4，P1〜P4 と呼ば れている (Fig. 3 参照). C0 地点においては深さ約 $40 \mathrm{~m}$ までの地盤調查が行われており, 地表から約 $5 \mathrm{~m}$ の深さ まではローム層（S 波速度 $140 \mathrm{~m} / \mathrm{s}$ )，それ以深は粘土 やシルトを含んだ砂首（ $\mathrm{S}$ 波速度 $320 \sim 420 \mathrm{~m} / \mathrm{s}$ ) と なっている. 3 次元的な震動性状についての検討が最終 目的であるが, 本論文においてはその第一段階として, 地下 $1 \mathrm{~m}$ の記録のみを用いた 2 次元的な震動卓越方向 についての検討を行った.

\section{§3. 强震動の卓越方向特性}

観測された地震動の卓越方向特性を調べるために, 地 震動の主軸解析は有用である[例えば, 星谷・石橋 (1977), Matsumura (1981), Montalbetti and KanASEWICH (1970)]. 本研究で用いる主軸は星谷・石橋 (1977) の定義による主軸 II に相当する，共分散マトリ クス

$$
V=\left(\begin{array}{lll}
\operatorname{Var}\left[x_{1}\right] & \operatorname{Cov}\left[x_{1} x_{2}\right] & \operatorname{Cov}\left[x_{1} x_{3}\right] \\
\operatorname{Cov}\left[x_{2} x_{1}\right] & \operatorname{Var}\left[x_{2}\right] & \operatorname{Cov}\left[x_{2} x_{3}\right] \\
\operatorname{Cov}\left[x_{3} x_{1}\right] & \operatorname{Cov}\left[x_{3} x_{2}\right] & \operatorname{Var}\left[x_{3}\right]
\end{array}\right)
$$

が各観測点の 3 成分の加速度記録から計算される， $x_{1}$, $x_{2}, x_{3}$ は 3 成分の加速度時刻歴であり, $\operatorname{Var}[\mathrm{C}$ と $\mathrm{Cov}$ [ ] はそれぞれ分散, 共分散を示している。 この共分散 
Table 1. List of Earthquakes.

\begin{tabular}{|c|c|c|c|c|c|c|}
\hline \multirow{2}{*}{ No. } & \multirow{2}{*}{ Date } & \multirow{2}{*}{ Time } & \multicolumn{2}{|c|}{ Epicenter } & \multirow{2}{*}{$\begin{array}{c}\text { Depth } \\
(\mathrm{km})\end{array}$} & \multirow{2}{*}{$M_{\text {JMA }}$} \\
\hline & & & Lat. $(\mathrm{N})$ & Long. (E) & & \\
\hline 7 & 1984. 12.17 & $23: 49: 47$ & $35^{\circ} 35.8^{\prime}$ & $140^{\circ} 03.5^{\prime}$ & 78 & 4.9 \\
\hline 8 & 1985. $6 . \quad 8$ & $01: 29: 01$ & $35^{\circ} 32.3^{\prime}$ & $140^{\circ} 14.9^{\prime}$ & 64 & 4.8 \\
\hline 9 & 1985. 10. 4 & $21: 25: 51$ & $35^{\circ} 52.1^{\prime}$ & $140^{\circ} 09.5^{\prime}$ & 78 & 6.1 \\
\hline 10 & 1985. 11. 6 & $00: 30: 50$ & $35^{\circ} 21.3^{\prime}$ & $140^{\circ} 14.4^{\prime}$ & 63 & 5.0 \\
\hline 15 & 1987. 6. 30 & $18: 17: 07$ & $36^{\circ} 11.0^{\prime}$ & $140^{\circ} 05.3^{\prime}$ & 57 & 4.9 \\
\hline 16 & 1987. 12.17 & $11: 08: 16$ & $35^{\circ} 22.3^{\prime}$ & $140^{\circ} 29.8^{\prime}$ & 58 & 6.7 \\
\hline 17 & 1987.12 .17 & $11: 15: 11$ & $35^{\circ} 21.7^{\prime}$ & $140^{\circ} 30.7^{\prime}$ & 52 & 4.6 \\
\hline 18 & 1987. 12.17 & $14: 07: 06$ & $35^{\circ} 23.6^{\prime}$ & $140^{\circ} 29.1^{\prime}$ & 58 & 4.4 \\
\hline 19 & 1987.12 .17 & $15: 29: 56$ & $35^{\circ} 19.5^{\prime}$ & $140^{\circ} 33.5^{\prime}$ & 42 & 4.0 \\
\hline 20 & 1988. 1. 5 & $10: 09: 02$ & $35^{\circ} 24.7^{\prime}$ & $140^{\circ} 26.0^{\prime}$ & 42 & 4.2 \\
\hline 21 & 1988. 1.16 & $20: 42: 11$ & $35^{\circ} 23.2^{\prime}$ & $140^{\circ} 24.8^{\prime}$ & 48 & 5.2 \\
\hline 22 & 1988. 1.18 & $19: 37: 14$ & $35^{\circ} 33.2^{\prime}$ & $139^{\circ} 56.6^{\prime}$ & 32 & 4.1 \\
\hline 23 & 1988. 3. 18 & $05: 34: 29$ & $35^{\circ} 39.7^{\prime}$ & $139^{\circ} 38.8^{\prime}$ & 96 & 6.0 \\
\hline 24 & 1988. 8. 12 & $14: 14: 53$ & $35^{\circ} 05.7^{\prime}$ & $139^{\circ} 52.0^{\prime}$ & 69 & 5.3 \\
\hline 25 & $1989 . \quad 2.19$ & $21: 27: 17$ & $36^{\circ} 01.1^{\prime}$ & $139^{\circ} 54.5^{\prime}$ & 55 & 5.6 \\
\hline 26 & 1989. 3. 6 & $23: 39: 44$ & $35^{\circ} 41.6^{\prime}$ & $140^{\circ} 42.8^{\prime}$ & 56 & 6.0 \\
\hline 27 & 1989. 3. 11 & $16: 12: 17$ & $35^{\circ} 54.5^{\prime}$ & $140^{\circ} 33.8^{\prime}$ & 45 & 4.9 \\
\hline
\end{tabular}

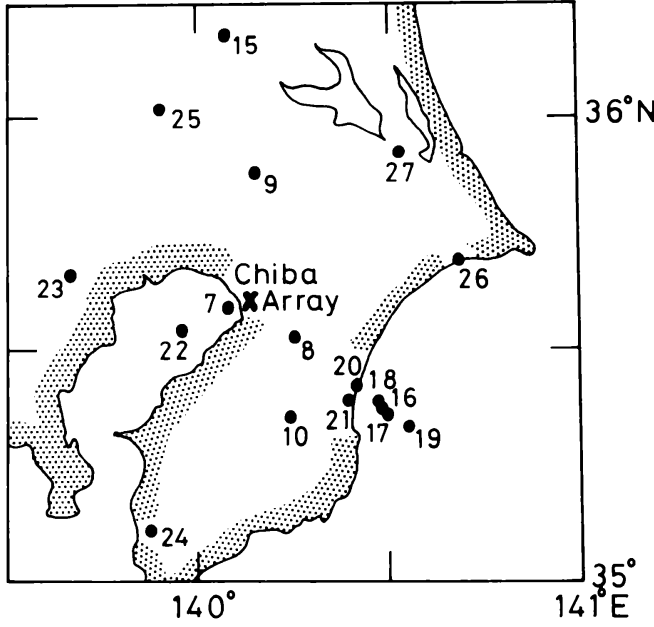

Fig. 1. Epicenters of earthquakes (solid circles) and the location of Chiba Array (cross).

マトリクスを対角化する座標变換行列として，3つの主 軸が求められる．最大固有値に対応する主軸を最大主 軸, 中間固有値に対応するものを中間主軸, 最小固有值 に対応するものを最小主軸之呼ぶ，各々の主軸の向きは 鉛直上方からの角度 $\theta$ と東から反時計回りに測った角 度 $\phi$ とによって表現できる. 最大主軸方向は地震時の強 震動の卓越方向に相当する．また，中間固有値の最大固 有値に対する比を $\gamma$ として, 地震動の偏向性の程度を表 わすパラメターとして用いる.

Fig. 2 に例示したように, S 波が卓越している付近に
5 秒間のウインドウをかけて取り出した記録に $0 \sim 2 \mathrm{~Hz}$, 2〜 $4 \mathrm{~Hz}, 4 \sim 6 \mathrm{~Hz}, 6 \sim 8 \mathrm{~Hz}, 8 \sim 10 \mathrm{~Hz}$ の 5 種類の帯域通 過フィルターをかけ, 主軸解析を行った. 地震動の主軸 方向は, 刻々到達する地震波の性質に従って時間的に変 化する，一般に，ウインドウ幅を広げると散乱波が多く 混入して $\gamma$ の值は大きくなり， $\phi$ の值は不安定になる. 本研究では, 直達 $\mathrm{S}$ 波から構成されている地震動を主に 抽出するため, ウインドウ幅を 5 秒とした。 得られた最 小主軸はほぼ鉛直であり， $\mathrm{S}$ 波卓越部分では地面はほぼ 水平に震動している.これ以後は簡単のために, 水平面 内における 2 次元の震動として現象を取扱い, 震動卓越 方向特性を最大主軸の方向 $\phi$, および, 中間固有値と最 大固有値の比 $\gamma$ という 2 つのパラメターで表現する.

例 として, $\mathrm{EQ} 16\left(M_{\mathrm{JMA}}=6.7\right), \mathrm{EQ} 20\left(M_{\mathrm{JMA}}=4.2\right)$, EQ23 $\left(M_{\mathrm{JMA}}=6.0\right)$ の 3 地震の震動卓越方向特性を Fig. 3 に示した. 図中の楕円の長軸方向が $\phi$ を, 短径と長径 の比が $\gamma$ を表現している. どの地震の場合をとっても， $0 \sim 2 \mathrm{~Hz}$ の震動卓越方向特性は 9 観測点間でよく揃つ ている.このことは 9 観測点が地震時に揃って震動して いたことを示す．ややばらつきが見られるものの，4〜6 $\mathrm{Hz}$ の周波数帯の結果も同様の傾向を示している. ただ し, 震動卓越方向は $0 \sim 2 \mathrm{~Hz}$ の場合と異なっている. 一 方, $\mathrm{EQ} 16$ と $\mathrm{EQ} 23$ の 8 $10 \mathrm{~Hz}$ の周波数帯における震 動卓越方向は，9観測点でだいぶばらついている．9観 測点は非常に近接しているので, 地震の震源の影響や震 源から千葉アレーに達する経路における地震波の散乱の 影響などは 9 観測点で同じと考えて良いだろう。した 

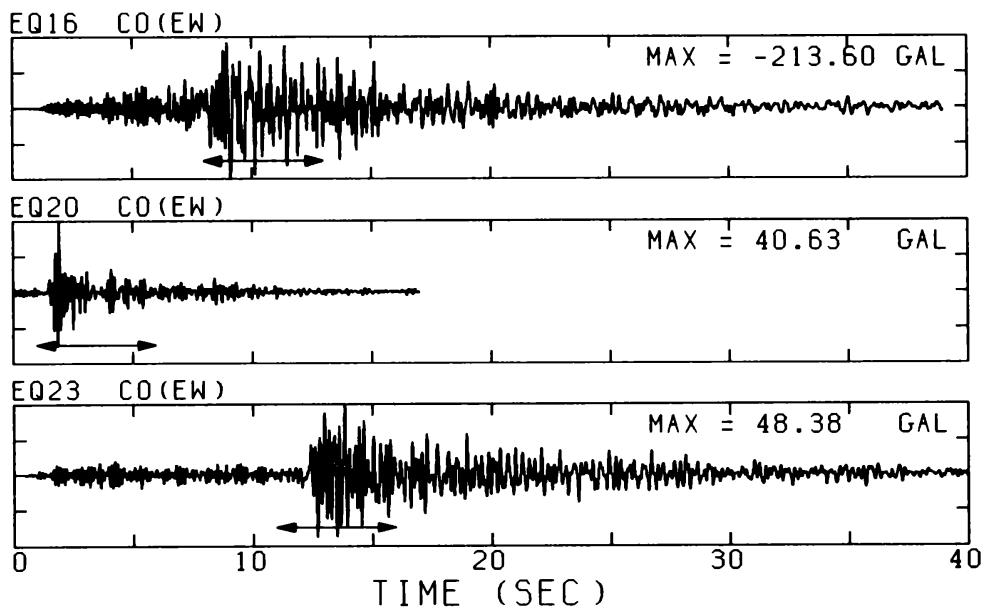

Fig. 2. Examples of accelerograms for EQ16 (upper), EQ20 (middle), and EQ23 (lower). The arrows indicate the width of data windows used in this study.

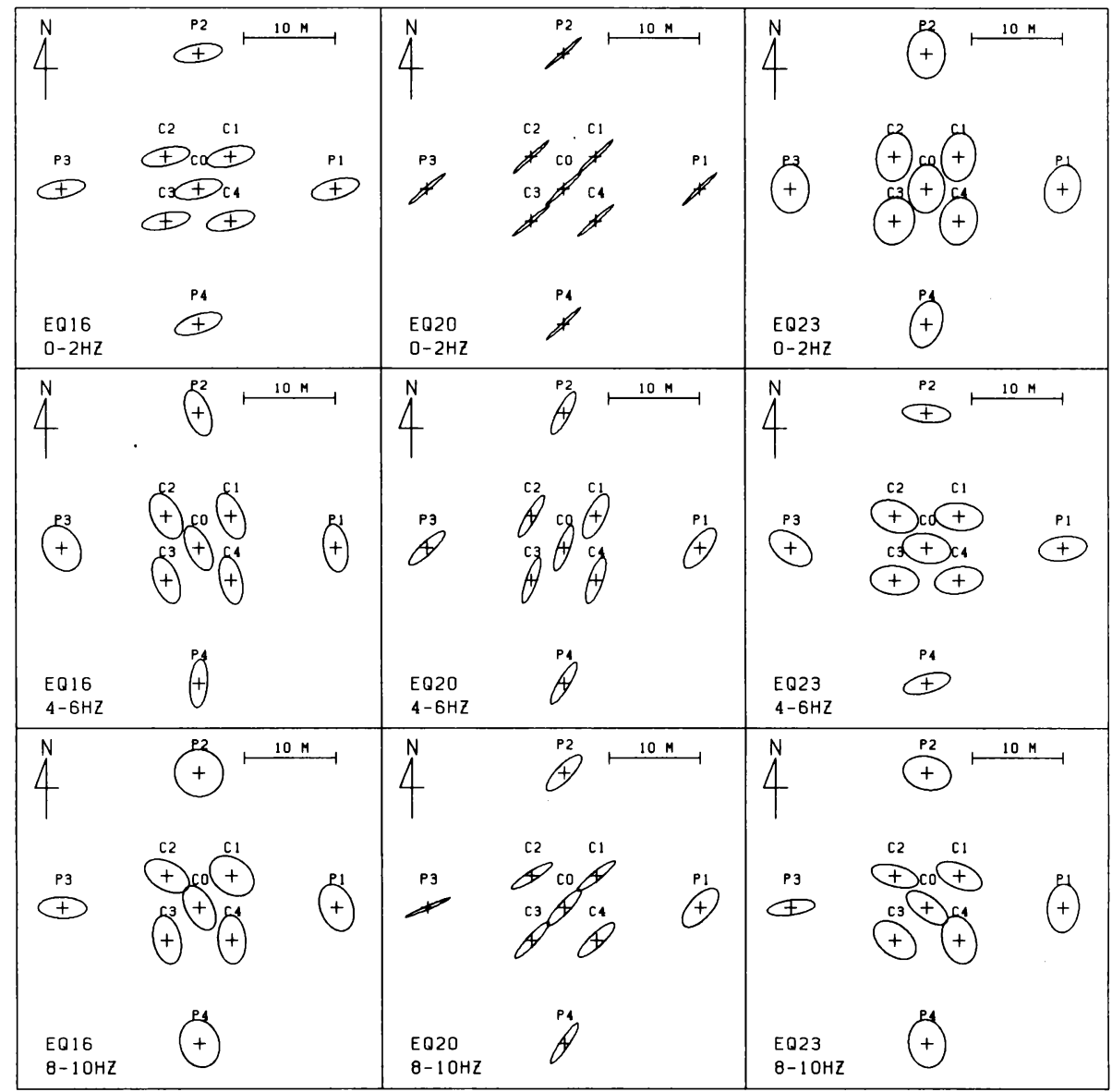

Fig. 3. Observed polarization characteristics of strong ground motions for EQ16, EQ20 and EQ23. The directions of the longer axes of the ellipses indicate the directions of the major principal axes of strong ground motions. The aspect ratios of the ellipses indicate the ratios of the second largest eigenvalue to the largest eigenvalue. 
がって，この違いを生ずる原因は各観測点のごく近傍の 地盤状態等にあると考えざるをえない. $\mathrm{EQ} 16$ と $\mathrm{EQ} 23$ の震動卓越方向の空間分布に注目すると, $8 \sim 10 \mathrm{~Hz}$ の 周波数帯では, 2 つ地震でよく似ていることに気づ く.このことは, VIDALE et al. (1991) が指摘しているよ うに, 各観測点が地震の際に摇れ易い方向を持っている ことを暗示する.しかしながら， EQ20 の 8〜 $10 \mathrm{~Hz}$ 帯 の震動卓越方向特性を見てみると，9観測点間であまり 差がなく, EQ16や EQ23 の場合とは明らかに異なる.

各観測点における 8〜 $10 \mathrm{~Hz}$ 帯の $\phi$ の値が, 異なる地 震に対してどの程度ばらついているかを Fig. 4 に示し

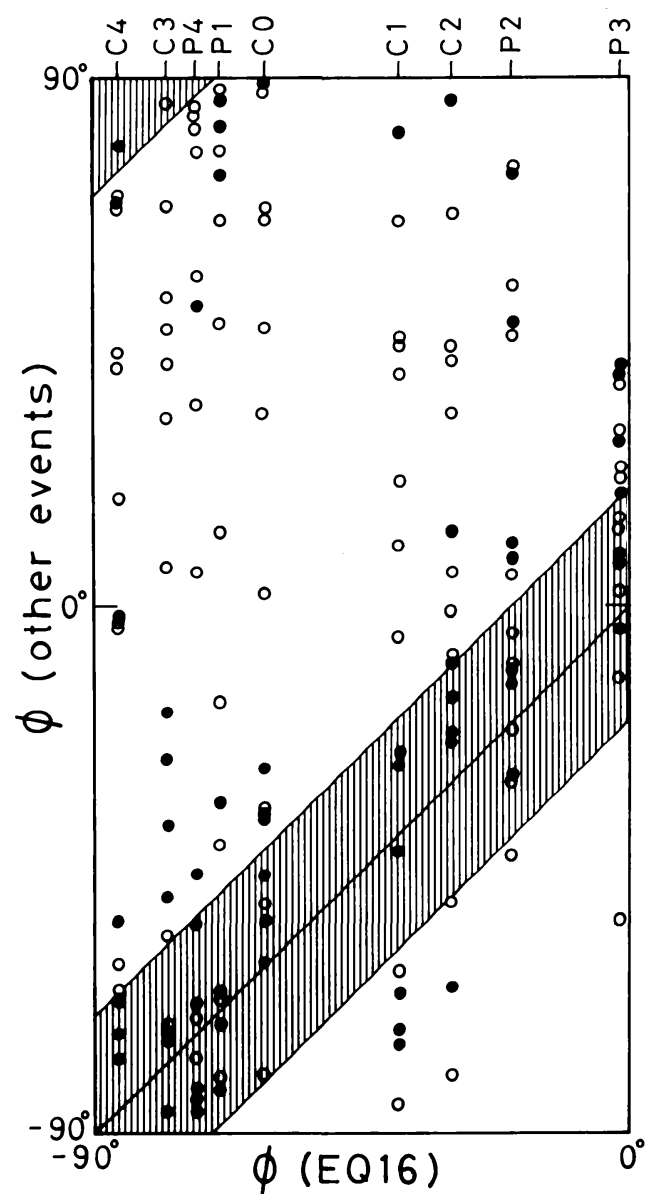

Fig. 4. Correlation between predominant directions $(\phi)$ of $8-10 \mathrm{~Hz}$ ground motions for $\mathrm{EQ}$ 16 and those for the other events at the observation points, $\mathrm{C} 0-\mathrm{C} 4$ and $\mathrm{P} 1-\mathrm{P} 4$. The solid circles indicate the predominant directions for the events with $M_{\mathrm{JMA}} \geq 5$ and the open circles are for the events with $M_{\mathrm{JMA}}<5$. The difference between $\phi$ 's for EQ16 and for the other events is less than $20^{\circ}$ in the shadowed zones.
た. 17 地震中最大の地震である EQ16 の 8 10 Hz 帯 の $\phi$ の值を横座標にとった. Fig. 4 上端に示された $\mathrm{C} 0$ 〜 $4, \mathrm{P} 1 \sim \mathrm{P} 4$ の記号の位置は, 各観測点における EQ16 の $\phi$ の値を示している. EQ16 以外の地震の 8〜 $10 \mathrm{~Hz}$ 帯の $\phi$ の值を縦座標にとり, 対応する観測点毎に プロットした。図中の黒丸は相対的に大きな地震 ( $M_{\mathrm{JMA}}$ Z5)についての結果, 白丸は相対的に小さな地震 $\left(M_{\mathrm{JMA}}\right.$ <5)についての結果を示している. もしも Directional Site Resonance が非常に支配的ならば，すべてのプ ロットが影をつけた領域内もしくはその周辺に集中する ことが期待される. Fig. 4 は, 相対的に大きな地震につ いてはこの傾向があることを示している. また, P3 地点 に関しては, 地震の大小にかかわらずこの傾向が認めら れる. しかし, P3 以外の観測点における相対的に小さい 地震についての結果は, たとえ Directional Site Resonance があったとしてもその影響は非常に小さいこと を示している. 従って, 実際に観測された震動卓越方向 特性を, 観測点固有の性質である Directional Site Resonance だけで説明することには無理があると言えよ う.

\section{§4. 强震動卓越方向の解秎}

観測された強震動の最大主軸と中間主軸は殆ど水平面 内にあるので, 前節でも述べたように, 強震動の卓越方 向特性を $2 つ$ つ゚ラメター $\left(\phi_{j \boldsymbol{k}}, \gamma_{j \boldsymbol{k}}\right)$ で表現する. ここ で， $j$ は地震， $k$ は観測点を表現するための添え字であ る. $\phi_{j k}$ は最大主軸の方向, $\gamma_{j k}$ は中間固有値之最大固有 値の比を表している.

さて, 観測された強震動の卓越方向特性 $\left(\phi_{j \boldsymbol{k}}, \gamma_{j \boldsymbol{k}}\right)$ は, 各地震に固有でかつ 9 観測点に共通する要素 $\left(\phi_{j}, \gamma_{j}\right)$ と, 地祳に無関係で各観測点に固有の要素 $\left(\phi_{k}, \gamma_{k}\right)$ の合成さ れた結果であると仮定する，震源での放射特性や震源か ら千葉アレーに至る伝播経路での地震波の散乱の影響等 は共通要素 $\left(\phi_{j}, \gamma_{j}\right)$ に含まれ, $\left(\phi_{j}, \gamma_{j}\right)$ はアレー全体の平 均的な震動卓越方向特性を表していると言い換えること あ出来よう.これに対して $\left(\phi_{k}, \gamma_{k}\right)$ は各観測点のごく近 傍の地盤状態等の影響を表しており，アレー全体の平均 的な震動場である $\left(\phi_{j}, \gamma_{j}\right)$ からの変動分に相当する.こ の変動分は, 地震波の到来方向の違いなどに伴って, 地 震毎に変化するものかもしれない. しかしここでは第一 近似として, $\left(\phi_{k}, \gamma_{k}\right)$ は地震に依存せず, 観測点に固有の 性質であると考える. 即ち, $\left(\phi_{k}, \gamma_{k}\right)$ は VIDALE et al. (1991) の言う Directional Site Resonance の非常に小 規模なものに相当する.

アレー全体の平均的震動場と観測点毎の变動分の合成 は, $\left(\phi_{j}, \gamma_{j}\right)$ で表される楕円の径之, $\left(\phi_{k}, \gamma_{k}\right)$ で表される楕 
円の径とを，各方向毎に積算することによって行われる と仮定する．ただし，そのように合成すると，結果が必 ずしあ棈円とはならない，そこで，実際には次に示す関 係式 (2) と (3) を用いて合成し, 合成結果を楕円で表現 出来るように, 即ち, 2 つのパラメター $\left(\phi_{j k}, \gamma_{j k}\right)$ のみで 表現出来るようにした。

$$
\phi_{j k}=\left(\begin{array}{l}
\phi_{j} \quad ; \phi_{j}=\phi_{k} \pm 90^{\circ} \text { and } \gamma_{j}<\gamma_{k} \\
\phi_{k} \quad ; \phi_{j}=\phi_{k} \pm 90^{\circ} \text { and } \gamma_{j}>\gamma_{k} \\
\frac{\left\{\gamma_{k}\left(1-\gamma_{j}\right)\right\} \phi_{j}+\left\{\gamma_{j}\left(1-\gamma_{k}\right)\right\} \phi_{k}}{\gamma_{k}\left(1-\gamma_{j}\right)+\gamma_{j}\left(1-\gamma_{k}\right)} \quad ; \text { otherwise }
\end{array}\right.
$$

$$
\gamma_{j k}=\left(\begin{array}{r}
\left(\gamma_{j} / \gamma_{k}\right) \sin ^{2}\left(\phi_{j}-\phi_{k}\right)+\gamma_{j} \gamma_{k} \cos ^{2}\left(\phi_{j}-\phi_{k}\right) \\
; \gamma_{j}<\gamma_{k} \\
\left(\gamma_{k} / \gamma_{j}\right) \sin ^{2}\left(\phi_{j}-\phi_{k}\right)+\gamma_{j} \gamma_{k} \cos ^{2}\left(\phi_{j}-\phi_{k}\right) \\
; \gamma_{j} \geq \gamma_{k}
\end{array}\right.
$$

式 (2), (3) を用いて $\left(\phi_{j}, \gamma_{j}\right)$ と $\left(\phi_{k}, \gamma_{k}\right)$ とを合成した例 をFig. 5 に示す. Fig. 5(a) は, 地震 $j$ の際にアレー全体 としては等方的に震動していたが，観測点 $k$ が Directional Site Resonance を生じたため, 観測された地震 動は卓越方向特性 $\left(\phi_{j k}, \gamma_{j k}\right)=\left(\phi_{k}, \gamma_{k}\right)$ を有するに至った ことを示している. また Fig. 5(b) は, 地震 $j$ の際にア レ一全体が震動卓越方向特性 $\left(\phi_{j}, \gamma_{j}\right)$ を有しており観測 点 $k$ では Directional Site Resonance を生じなかった とすると, 観測された地震動は卓越方向特性 $\left(\phi_{j k}, \gamma_{j k}\right)=$ $\left(\phi_{j}, \gamma_{j}\right)$ を有することを示している. Fig. 5(c) はアレー全 体がある震動卓越方向特性を示し, 観測点も Directional Site Resonance を示すというような一般的な場合を 示している，あちろん，式 (2), (3) に変えてもっ之複雑な 関数を考えることも可能であろう．しかし，今回のよう

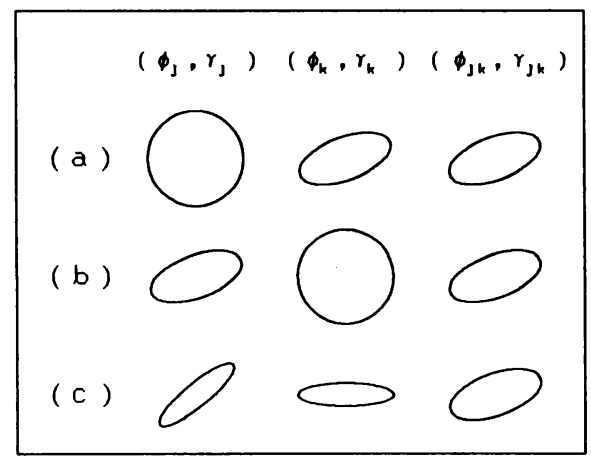

Fig. 5. Schematic illustration of relations among polarization characteristics of strong ground motions averaged over the observation points $\left(\phi_{j}, \gamma_{j}\right)$, directional site resonance $\left(\phi_{k} \gamma_{k}\right)$, and observed polarization characteristics of strong ground motions $\left(\phi_{j b_{0}} \gamma_{j k}\right)$.
な定性的な議論において，あまり複雑な関数を導入する ことは意味がない

ところで, Fig. 3 に示された $0 \sim 2 \mathrm{~Hz}$ の周波数帯の場 合のように 9 観測点が揃って震動していたら, それが Fig. 5 のどの場合の結果であるのか識別不可能である. 以下においては 9 観測点間で震動卓越方向が最もばら ついていた 8〜 $10 \mathrm{~Hz}$ の周波数帯について, 観測された $\left(\phi_{j k}, \gamma_{j k}\right)$ を $\left(\phi_{j}, \gamma_{j}\right)$ と $\left(\phi_{k}, \gamma_{k}\right)$ とに分離することを試み る.ここで行おうとする手法で低周波数帯の震動卓越方 向特性を扱うためには, あっと大規模なアレーの記録を 解析する必要があろう.

先ず， $\gamma_{k}$ の初期値を全ての観測点で 1.0 とした. そし て， $\phi_{j}$ を 1 度ずつ, $\gamma_{j}$ を 0.05 ずつ変化させながら

$$
\epsilon=\sum_{j=1}^{17} \sum_{k=1}^{9}\left\{\left(\phi_{j k}^{(0)}-\phi_{j k}^{(c)}\right)^{2}+\left(\gamma_{j k}^{(0)}-\gamma_{j k}^{(c)}\right)^{2} w^{2}\right\} \rightarrow \text { minimum }
$$

という条件の下で $\phi_{j}$ と $\gamma_{j}$ の第 1 近似值を求めた. ここ で, $\quad w$ は $\phi_{j k}$ の一致程度と $\gamma_{j k}$ の一致程度とのどちらに よ゙の程度の重きを置くかについての係数であり, 試行錯 誤の結果 100.0 とした. 添え字 (o) と (c) はそれぞれ観 測値および式 (2), (3) による計算値であることを示して いる. 次に, $\left(\phi_{j}, \gamma_{j}\right)$ を第 1 次近似值に固定し, $\left(\phi_{k}, \gamma_{k}\right)$ の 第 1 近似值を求めた. この操作を, $\left(\phi_{j}, \gamma_{j}\right)$ と $\left(\phi_{k}, \gamma_{k}\right)$ が 前回の近似値から变化しなくなるまで繰り返した。

観測された $\left(\phi_{j k}, \gamma_{j k}\right)$ から $\left(\phi_{j}, \gamma_{j}\right)$ と $\left(\phi_{k}, \gamma_{k}\right)$ とを一意的 に得ることは不可能であり, 異なる初期値から出発すれ ば異なる解に収束するであろう。本論文において初期値

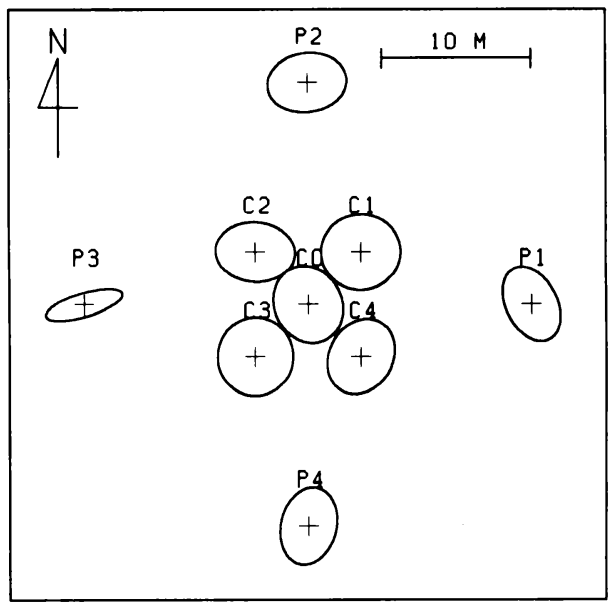

Fig. 6. Directional site resonance characteristics. The directions of the longer axes of the ellipses indicate the preferred directions of strong amplification at the observation points. The aspect ratios indicate the degree of the directional site resonance. 
を $\gamma_{k}=1.0$ としたことは, $\left(\phi_{j}, \gamma_{j}\right)$ をアレー全体の平均的 な震動場に関するもの， $\left(\phi_{k}, \gamma_{k}\right)$ を平均的震動場からの 変動分を表すすのとして取り扱っていることに基づいて いる. したがって，入射して来た地震波を強く変形する ような特性を観測点が持っていたとしても，それが 9 観 測点に共通するあのであれば，その影響は $\left(\phi_{k}, \gamma_{k}\right)$ では なく $\left(\phi_{j}, \gamma_{j}\right)$ に含まれることになる.

以上の操作によって得られた観測点の特性 $\left(\phi_{k}, \gamma_{k}\right)$ を Fig. 6 に示した. P3 地点は, 非常に強い東西方向の Directional Site Resonance を示している.このことは,

Fig. 4 のP3 地点に関するプロットが, 他の地点に比べ て狭い範囲にまとまっていたことからあ予想されたこと である．概してそれほど強くはないが，他の観測点も Directional Site Resonance を示していることが分か る. 地盤が水平方向に均質でないこと, 例えば, 地震波 速度に異方性やゆらぎがあることなどが Directional Site Resonance を生ずる原因かもしれない，そのメカ
ニズムを解明するためには，更なる検討が必要である．

Fig. 7, Fig. 8 には各地震の際の $\left(\phi_{j}, \gamma_{j}\right)$ 及び震動卓越 方向特性の観測値 $\left(\phi_{j k}^{(o)}, \gamma_{j k}^{(o)}\right)$ と計算値 $\left(\phi_{j k}^{(c)}, \gamma_{j k}^{(c)}\right)$ とが示され ている. EQ18 の場合, および, P1 地点と P4 地点にお いて幾らか不満足な点が見られるが, 計算結果は観測結 果を概してうまく説明している.これらの図をみると, 比較的大きな地震の際に観測された震動卓越方向特性は 概して Fig. 6 の観測点特性 $\left(\phi_{k}, \gamma_{k}\right)$ に似ていることに気 づく. 一方, 比較的小地震については, 各図左上隅に示 されたアレー全体の震動卓越方向特性 $\left(\phi_{j}, \gamma_{j}\right)$ がほとん どそのまま観測された震動卓越方向特性に反映されてい る場合が多い.この現象を, 小地震の場合には入射して きた地震波が非常に強く偏向していたため，入射波の偏 向特性が観測された強震動の震動卓越方向特性にそのま ま反映された結果である，と解釈することも出来るだろ j.

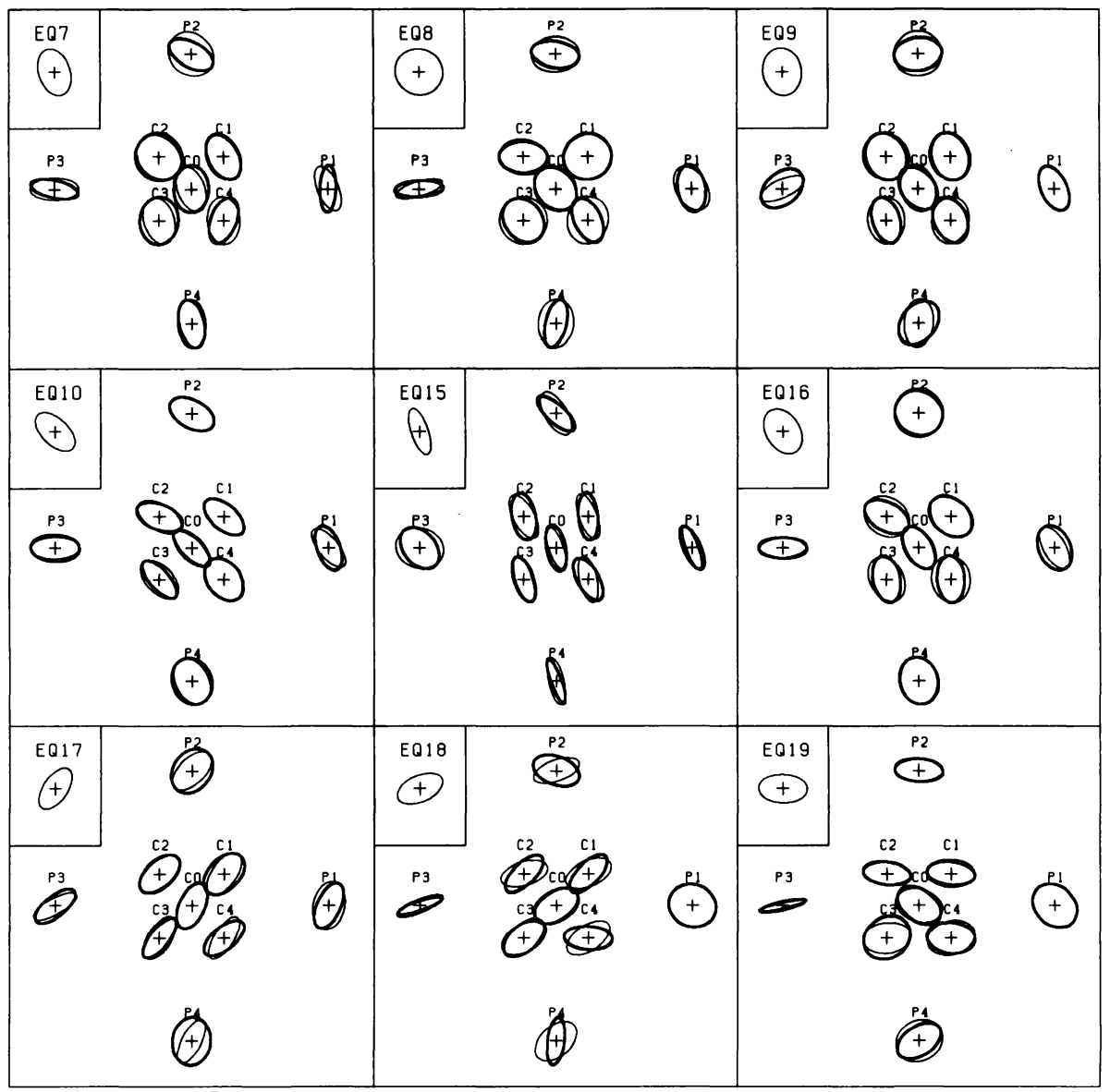

Fig. 7. Polarization characteristics of strong ground motion averaged over the observation points for each event (left-hand corner), fitted polarization characteristics of strong ground motions (thin ellipses), and observed ones (thick ellipses) for EQ7-EQ19. 


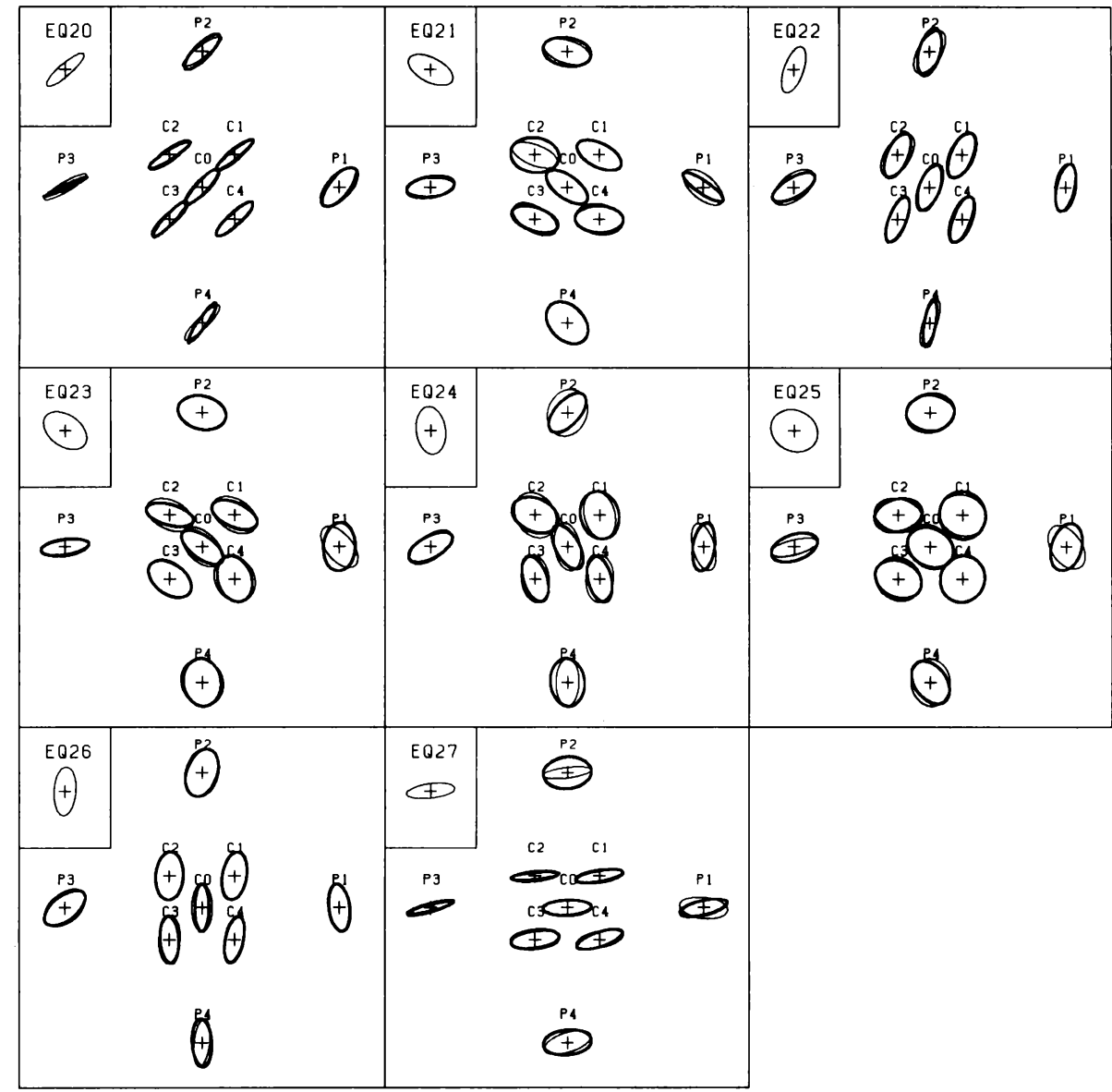

Fig. 8. Polarization characteristics of strong ground motion averaged over the observation points for each event (left-hand corner), fitted polarization characteristics of strong ground motions (thin ellipses), and observed ones (thick ellipses) for EQ20-EQ27.

\section{§5. 震源の影霎}

本研究で解析した 17 個の地震のうち, 1987 年千葉県 東方沖地震の本震 $(\mathrm{EQ} 16)$ とその最大余震 $(\mathrm{EQ} 21)$ につ いては，P波初動の分布から発震機構解が求められてい る [福山・木下 (1989), 草野・吉田 (1990)]. 半無限弾 性体内に点震源を仮定して千葉アレーでの S 波の震動 方向を計算した，震源での射出角を鉛直下方から $110^{\circ}$ $\sim 120^{\circ}$, 表層への入射角を $0^{\circ} \sim 20^{\circ}$ と仮定すると, 千葉 アレーでの S 波の震動方向は, $\mathrm{EQ} 16$ では約 $\mathrm{E} 40^{\circ} \mathrm{S}$, $\mathrm{EQ} 21$ では約 $\mathrm{E} 10^{\circ} \mathrm{S}$ となる.これらの值は Fig. 7, Fig. 8 に示されたアレー全体の震動卓越方向 $\phi_{j}$ として求め られた結果と調和的である.このことは，前節において アレー全体の平均的震動卓越方向特性 $\left(\phi_{j}, \gamma_{j}\right)$ として求 められたものが, アレーに入射して来た地震波の偏向特 性を表わしているということを暗示する. したがって, 観測された 8〜 $10 \mathrm{~Hz}$ 帯の強震動の震動卓越方向は, 観
測点での Directional Site Resonance の影響を受けつ つも，地震の発震機構を反映していると言うことも出来 よう.

ところが, Fig. 3 の EQ16 の 0 2 Hz の場合をみる と, その震動卓越方向は 8〜 $10 \mathrm{~Hz}$ についての $\phi_{j}$ とは異 なっており，ここで計算してみた発震機構から期待され る S 波の震動方向とも合わない. その周波数帯域の地震 波の波長でスケーリングされるような大規模な Directional Site Resonance を反映しているのかむ知れない. この点を明確にするためには，むっと大規模なアレ一記 録を解析する必要がある.

Fig. 7,Fig. 8 に見られるようにアレー全体の平均的 震動場の偏向性はそれほど強くない，EQ20 の場合が最 も強いが，それでも $\gamma_{j} に し て 0.25$ である. 震源から千 葉アレーに至る間の経路における地震波の散乱効果が地 震動の偏向性を弱めるために主要な働きをしているので 
あろう.ところで，その地震波の散乱効果は，EQ16〜 EQ21 に関しては震源位置が近いため, 同程度と考えて あ良いであろう. Fig. 7 と Fig. 8 をみると, EQ16 のア レ一全体の平均的震動場の偏向性は他の地震の場合に比 べて弱い．これを説明するためには地震波の散乱効果以 外の要因を考えに入れる必要があろう，EQ16 の断層の 大きさは $21 \times 24 \mathrm{~km}^{2}$ と推定されている[福山・木下 (1989)]. 地震マグニチュードの違いを考えると, EQ16 の断層は余震のそれらに比べて格段に大きいことが予想 される. 大きな断層面上での短周期波の射出パターン が，場所によらず一様であるとは考えにくい，たとえ一 様であったとしても，断層の各点から射出された $\mathrm{S}$ 波が 混じりあって入射波の偏向性を弱める㗢きをするであろ う.したがって, 地震断層が大きいことや一様でないこ とは，入射して来る波の偏向性を弱める働きをすると考 えられる. その結果, 観測される強震動の卓越方向特性 は観測点の持つ性質である Directional Site Resonance をより明確に反映することになったのであろう。

\section{§6. 結論}

密に配置された加速度計アレー記録を解析し， 17 個 の地震の 8〜 $10 \mathrm{~Hz}$ の周波数帯における $\mathrm{S}$ 波による震動 卓越方向特性について検討した。観測された強震動卓越 方向特性は, 偏向した入射波の性質と観測点固有の Directional Site Resonance の影響の両者が入り混じった 結果と解釈できる。ここで取り扱ったような震央距離 （70 km 以内）については, $M_{\mathrm{JMA}} \geq 5$ の地震の際に観測 された強震動卓越方向特性は観測点固有の Directional Site Resonance を比較的よく反映している。ここれは断 層が大きいことや一様でないために，入射してきた地震 波か強い偏向性を有していなかったためと考えられる. これに反して $M_{\mathrm{JMA}}<5$ の地震の場合には, 入射してき た地震波の偏向性が強いため, 入射波の偏向特性がその まま地表の強震動卓越方向特性にに反映されている.

1987 年千葉県東方沖地震の本震と最大余震の場合に ついては， 8〜 $10 \mathrm{~Hz}$ 帯のアレー全体の平均的震動卓越 方向と発震機構から期待される $\mathrm{S}$ 波の震動方向とは調 和的であった。 しかし, 周波数帯が違えば情況が異なっ ている可能性がある。

\section{謝辞}

千葉アレーのデータは東京大学生産技術研究所片山研 究室よりお借りした，記して感謝します．本研究は文部 省科学研究費の補助（課題番号 03201214）を受けて行 われた。

\section{文献}

AKI, K. and K. L. LARner, 1970, Surface motion of a layered medium having an irregular interface due to incident plane SH waves, J. Geophys. Res., 75 , 933-954.

Bonamassa, O. and J. E. Vidale, 1991, Directional site resonance observed from aftershocks of the 18 October 1989 Loma Prieta earthquake, Bull. Seism. Soc. Am., 81, 1945-1957.

福山英一・木下繁夫, 1989,1987 年千葉県東方沖地震 の破壊過程の推定一経験的グリーン関数を用いた解 析一, 地震 $2,42,39-48$.

Herrmann, R. B., 1976, Some more complexity in S-wave particle motion, Bull. Seism. Soc. Am., 66, 625-632.

堀家正則・竹内吉弘・桑田和宏, 1991, 地盤の S 波の摇 らぎの統計的性質, 地震 2, 44, 267-269.

星谷 勝・石橋 裕, 1977, 地震動ベクトルの主軸之波 形特性，土木学会論文報告集，268，33-46.

入倉孝次郎, 1990, 経験的グリーン関数法, 文部省科学 研究費重点領域研究, 強震動および津波の予測と破壊 能評価に関する研究, 11-17.

Katayama, T., F. Yamazaki, S. Nagata, L. Lu and T. TÜrKER, 1990a, Development of strong motion database for the Chiba seismometer array, Report No. 90-1(14), Institute of Industrial Science, University of Tokyo, $100 \mathrm{pp}$.

Katayama, T., F. Yamazaki, S. Nagata, L. Lu and T. TÜRKER, 1990b, A strong motion database for the Chiba seismometer array and its engineering analysis, Earthq. Eng. Struct. Dyn., 19, 1089-1106.

KAw ASE, H. and K. AKI, 1990, Topography effect at the critical SV-wave incidence: possible explanation of damage pattern by the Whittier Narrows, California, earthquake of 1 October 1987, Bull. Seism. Soc. Am., 80, 1-22.

草野富士雄・吉田明夫, 1990,1987 年千葉県東方沖地 震の余震活動, 地震 2, 43, 459-469.

Matsumura, S., 1981, Three-dimensional expression of seismic particle motions by the trajectory ellipsoid and its application to the seismic data observed in the Kanto district, Japan, J. Phys. Earth, 29, 221-239.

Montalbetti, J. F. and R. Kanasewich, 1970, Enhancement of teleseismic body phases with a polarization filter, Geophys. J. Roy. Astr. Soc., 21, 119-129.

Nuttli, O., 1961, The effect of the Earth's surface on the $\mathrm{S}$ wave particle motion, Bull. Seism. Soc. Am., 51, 237-246.

佐藤春夫, 1991, ランダムな不均質による地震波の散 乱, 地震 2,44 , 特集号, 85-97.

佐藤暢彦・片山恒雄, 1983, 地中地震計の埋設方位の推 定, 第 17 回地震工学研究発表会講演概要, 土木学会, 115-118.

佐藤魂夫 - 中田 高 - 今泉俊文 - 大槻憲四郎, 1979, 被 
害調査から推定される地震動の卓越方向と地震断層モ デルー1976 年 7 月 5 日鬼首地震一, 地震 $2,32,171-$ 182.

Toksöz, M. N., A. M. Dainty and E.E. Charrette, 1991, Coherency of ground motion at regional distances and scattering, Phys. Earth Planet. Interiors, 67, 162-179.

植竹富一・真下 貢 - 天池文男, 1991, やや長周期地震 動を用いた地中埋設地震計の方位推定, 地震 2, 44, 151-154.
Vidale, E., O. Bonamassa and H. Houston, 1991, Directional site resonance observed from the 1 October 1987 Whittier Narrows, California, Earthquake and the 4 October aftershock, Earthquake Spectra, 7, 107-125.

Yamazaki, F., L. Lu and T. Katayama, 1992, Orientation error estimation of buried seismographs in array observation, Earthq. Eng. Struct. Dyn., 21, 679-694. 